\title{
Hypercalcaemia in rheumatoid arthritis: investigation of its causes and implications
}

\author{
ALASTAIR C. KENNEDY, BAGHAT F. ALLAM, PATRICK J. ROONEY, \\ MICHAEL E. WATSON, ANGELA FAIRNEY, ${ }^{1}$ KEITH D. BUCHANAN, ${ }^{2}$ \\ AND CATHERINE J. HILLYARD ${ }^{3}$
}

From the Centre for Rheumatic Diseases and University Departments of Medicine, Pathological Biochemistry, and Surgery, Glasgow Royal Infirmary, Glasgow, the ${ }^{1}$ Department of Chemical Pathology, St Mary's Hospital and Medical School, University of London, London, the ${ }^{2}$ University Department of Medicine, Queen's University, Belfast, and the ${ }^{3}$ Endocrine Unit, Royal Postgraduate Medical School, Hammersmith Hospital, London

SUMMARY When correction was made for hypoalbuminaemia, 23 of 50 ambulant patients with definite or classical rheumatoid arthritis were found to have hypercalcaemia. When these 23 patients were studied 6 months later, 7 had hypercalcaemia as defined by the correction factor for a low serum albumin level, and 6 of these patients had raised serum ionised calcium concentrations. Biochemical studies in the 23 patients indicated evidence of hyperparathyroidism, namely, hypophosphataemia, increased serum alkaline phosphatase, hyperchloraemia, and reduced tubular reabsorption of calcium. However, serum immunoreactive parathyroid hormone concentrations were normal. Only one patient had an abnormally low serum 25-hydroxy-vitamin D result: this patient had a high level of urinary D-glucaric acid and was receiving phenobarbitone for treatment of epilepsy. The biochemical features suggestive of parathyroid overactivity were particularly found in patients with raised serum calcium levels. The cause of hypercalcaemia in rheumatoid arthritis remains to be explained.

Osteoporosis is common in patients with rheumatoid arthritis even without corticosteroid therapy. Radiological studies have shown that osteoporosis is generalised, occurring to the same degree in all parts of the peripheral skeleton (Kennedy and Lindsay, 1977). Rarely, osteomalacia may be found in patients with rheumatoid arthritis, usually in elderly patients confined to home (Maddison and Bacon, 1974). However, most physicians would probably not consider that there was a general metabolic bone disorder underlying osteoporosis in rheumatoid arthritis. We were therefore surprised to find an unexpectedly high prevalence of hypercalcaemia in patients with the disease (Kennedy

Accepted for publication 20 October 1978

Correspondence to Dr Kennedy at Division of Rheumatology, Dept. of Medicine, State University of New York, Buffalo, 3495 Bailey Ave., Buffalo, NY 14215, USA. et al., 1975), and this paper describes further studies on the pathogene $;$ is of this hypercalcaemia.

\section{Material and methods}

\section{PATIENTS ST UDIED}

Twenty-three of 50 randomly selected female patients suffering from 'definite' or 'classical' rheumatoid arthritis, as defined by the diagnostic criteria of the American Rheumatism Association (Ropes et al., 1959) were found to be hypercalcaemic, that is, serum calcium concentration greater than $2.60 \mathrm{mmol} / \mathrm{l}$ when the total serum calcium concentration was corrected for the corresponding albumin concentration as outlined below. All these 23 patients were ambulant and all participated in the study with full knowledge of its content. All blood samples

Table 1 Clinical and laboratory data of the patients with rheumatoid arthritis included in the study $(n=23)$

\begin{tabular}{|c|c|c|c|c|c|c|c|c|c|}
\hline & Age (years) & $\begin{array}{l}\text { Duration of } \\
\text { arthritis } \\
\text { (years) }\end{array}$ & $\begin{array}{l}\text { Functional } \\
\text { grade }\end{array}$ & $\begin{array}{l}\text { Age at } \\
\text { menopause } \\
\text { (years) }\end{array}$ & $\begin{array}{l}\text { Duration } \\
\text { since } \\
\text { menopause } \\
\text { (years) }\end{array}$ & $\begin{array}{l}\text { Rheumatoid } \\
\text { factor } \\
\text { titre }\end{array}$ & $\begin{array}{l}\text { Antinuclear } \\
\text { factor } \\
\text { titre }\end{array}$ & $\begin{array}{l}\text { Haemoglobin } \\
\text { concen- } \\
\text { tration } \mathrm{g} / \mathrm{l}\end{array}$ & $\begin{array}{l}\text { Erythrocyte } \\
\text { sedimen- } \\
\text { tation rate } \\
\mathrm{mm} / 1 \mathrm{~h}\end{array}$ \\
\hline Mean \pm SD & $51 \cdot 7 \pm 15 \cdot 6$ & $6 \cdot 0 \pm 6 \cdot 6$ & $1 \cdot 7 \pm 0.6$ & $45 \cdot 5 \pm 2 \cdot 3$ & $15 \cdot 6 \pm 7 \cdot 3$ & $18 \cdot 2 \pm 22 \cdot 9$ & $217 \pm 513$ & $12 \cdot 2 \pm 1 \cdot 4$ & $52 \cdot 5 \pm 33 \cdot 5$ \\
\hline
\end{tabular}


were obtained without haemostasis between 8.30 and 9.30 a.m., the patients having fasted and taken no medication since $6 \mathrm{p} . \mathrm{m}$. the evening before. Prior to the study all patients were taking medication: 1 patient was receiving digoxin and a diuretic, 1 was on phenobarbitone for epileptic seizures, 3 were receiving low-dose corticosteroid therapy, that is, less than $10 \mathrm{mg}$ prednisolone per day, and the remainder were receiving a variety of non-steroidal anti-inflammatory analgesics. The clinical and laboratory data of the 23 patients are summarised in Table 1.

\section{DESIGN OF CORRECTION OF SERUM} CALCIUM CONCENTRATION FOR HY POALB UMINAEMIA

The serum calcium levels were corrected for albumin employing a formula derived in the following way. A regression analysis of calcium on albumin was carried out on the results from 150 normal healthy persons, half of whom were female. Their age ranges were as follows: 17 to 69 years for females, and 18 to 70 years for males. A regression equation was then calculated on the total 150 subjects. It is of interest that when the serum albumin concentration was zero the regression line cut the $\mathrm{Y}$ axis at $1.43 \mathrm{mmol} / \mathrm{l}$, which represents the ultrafiltrable calcium concentration, and corresponds to that found by Robertson (1969) (1.40 mmol/l); Pedersen (1970) (1.40 mmol/l); Rose (1972) $(1.45 \mathrm{mmol} / \mathrm{l})$; and Payne et al., (1973) (1.42 mmol/1) Orrell (1971) found a somewhat higher value for ultrafiltrable calcium $(1.70 \mathrm{mmol} / \mathrm{l})$, probably in part because the subjects studied included patients with nephrotic syndrome, a condition in which there is evidence of a tendency to hypercalcaemia (Jones et al., 1967).

The regression equation derived from the analysis was:

$\begin{array}{ll} & \mathrm{Y}=(\mathbf{0 . 0 1 9 4} \times \mathrm{X})+\mathrm{C} \\ \text { where } & \mathrm{X}=\text { serum albumin in } \mathrm{g} / \mathrm{l} \\ & \mathrm{Y}=\text { serum calcium in } \mathrm{mmol} / \mathrm{l} \\ \text { and } & \mathrm{C} \text { is a constant equal to } 1.434 \\ \text { (value of } \mathrm{Y} \text { when } \mathrm{X}=\mathrm{O}) \text {. }\end{array}$

The mean albumin for the population was $47.0 \mathrm{~g} / \mathrm{l}$, and the following correction factor for serum calcium concentration was constructed: $\mathrm{Ca}$ (corrected $)=(47-$ alb. $) \times 0.0194+\mathrm{Ca}$ where $\mathrm{Ca}$ is the measured serum calcium is $\mathrm{mmol} / \mathrm{l}$, alb. is the serum albumin in $\mathrm{g} / \mathrm{l}$, and $\mathrm{Ca}$ (corrected) is the serum calcium in $\mathrm{mmol} / 1$ corrected for albumin.

This indicates that calcium concentration changes by $0.0194 \mathrm{mmol} / 1$ for every $1 \mathrm{~g} / 1$ change in albumin and that therefore for every $1 \mathrm{~g} / 1$ by which the plasma albumin exceeds the normal mean of $47.0 \mathrm{~g} / 1$ 0.0194 is subtracted from the total plasma calcium and a corresponding addition is made when plasmac̣? albumin is less than $47.0 \mathrm{~g} / \mathrm{l}$.

In addition, a biochemical mineral metabolism $\stackrel{5}{?}$ screen was carried out on each subject. This involved $\frac{}{C}$ utilising data from blood and urine to calculate $\frac{\overline{\bar{c}}}{\bar{\rho}}$ certain derived values: (1) fasting urinary calcium $/ \overrightarrow{\widehat{\sigma}}$ creatinine ratio; (2) urinary calcium excretion $\left(\mathrm{Ca}_{\mathrm{E}}\right) \propto$ per litre glomerular filtrate (Nordin et al., 1967); (3) theoretical maximum tubular reabsorption $\vec{\circ}$ capacity $(\mathrm{Tm})$ for calcium, TmCa (Nordin et al., 1976); (4) the most reliable indices of renal handling $\omega$ of phosphate (Peterson, 1973), i.e., $\mathrm{TmPO}_{4}$ GFR (theoretical tubular maximum reabsorption ofō phosphate corrected for glomerular function (Bijvoet, $\omega_{\infty}^{\omega}$ 1969; Bijvoet et al., 1969) and IPE (index of phos-ir phate excretion) (Nordin and Bulusu, 1968).

The derivation and rationale of employing the $\mathrm{Ca}_{\mathrm{E}}$ per litre GF and the TmCa are well described by Marshall (1976) and by Nordin, Horsman and Aaron (1976). The calculation of these indices was carried out in the MRC Mineral Metabolism Unito at Leeds Royal Infirmary, and we are grateful for $\frac{\mathbb{Q}}{-}$ the co-operation extended by Professor B. E. C. $\overrightarrow{0}$ Nordin and colleagues.

\section{MEASUREMENT OF SERUM IONISED} CALCIUM

A $10 \mathrm{ml}$ clotted sample of blood, from which air was excluded immediately after withdrawal, was $\stackrel{\unrhd}{\varrho}$ used for the estimations of ionised calcium. Serum $\overrightarrow{\vec{B}}$ ionised calcium concentration was measured with a 3 flow-through electrode system (Orion 99-20) in which the electrodes were maintained at $37^{\circ} \mathrm{C}$ in a thermostatically controlled cabinet. At each measurement run the electrode was calibrated for directô․ sodium interference as well as for its response to standard calcium solutions, since the effect of sodium on the electrode has been found to vary (Watson, $\frac{\text { ? }}{3}$ 1975). Immediately after each measurement of

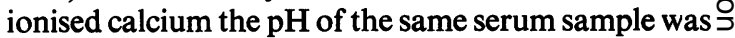
measured at $37^{\circ} \mathrm{C}$ with a glass capillary electrode system (EIL Model SHH 33).

Corrections were applied to the observed ionised $N$ calcium results to take account of direct sodium ${ }_{N}$ interference, and for this purpose a linear relationship was assumed between $\log \left(\mathrm{Ca}^{++}\right)$and sodium ${ }^{\omega}$ concentration (Watson, 1975). The ionised calcium at the measured $\mathrm{pH}$ was then adjusted to corres-0 pond to a standard $\mathrm{pH}$ value of 7.40. For any serum specimen the relationship between the logarithm of the ionised calcium concentration and $\mathrm{pH}$ is linear, but the slope of the regression line varies with $\overrightarrow{\mathbb{D}}$ albumin concentration and, to a lesser degree, with $\stackrel{\odot}{\Phi}$ the actual ionised calcium level. Accordingly, in order $\odot$ to make $\mathrm{pH}$ corrections this slope was calculated 
for each sample by a formula derived from theoretical studies of calcium binding to albumin (Pedersen, 1972) and from the results of observations of the influence of $\mathrm{pH}$ on serum ionised calcium with varying albumin and calcium concentrations (Watson, 1975). The reproducibility of this method has been shown to be highly satisfactory, with a coefficient of variation of $0.76 \%$ (Watson, 1975). The normal range of serum ionised calcium concentration was established in an age- and sexmatched group of healthy persons who were either members of staff or related to members of staff of the Centre for Rheumatic Diseases and in whom there was no evidence of disease associated with disturbance of calcium metabolism. These blood samples were also obtained in the fasting state and under the same stringent conditions described for the patient group.

\section{OTHER ASSAYS}

Serum immunoreactive parathormone was measured by Dr Angela Fairney of St Mary's Hospital (Fairney et al., 1973) and by Mrs Catherine Hillyard of the Royal Postgraduate Medical School in London (Berson et al., 1963). Calcitonin assays were performed by the latter (Coombes et al., 1974). Estimation of serum 25-hydroxy-vitamin $D$ was performed by the method of Haddad and Chyu (1971) using vitamin-D-replete rat kidney cytosol protein (McLaughlin et al., 1974). Other assays included serum immunoreactive gastrin (Buchanan and McCarrol, 1971), serum immunoreactive pancreatic glucagon (Buchanan, 1973; Flanagan et al., 1974), urinary D-glucaric acid excretion (Simmons et al., 1974), and urinary hydroxyproline (Goverde and Veenkamp, 1972).

In all assays reference data were obtained from estimations performed on fasting subjects matched for age and sex.

\section{RADIOLOGICAL ASSESSMENT}

Radiological films of the hands and wrists were assessed for joint space narrowing and erosions by the method described by Sharp et al. (1971). The metacarpal index of Barnett and Nordin (1960) was used as a measurement of osteoporosis.

\section{STATISTICAL METHODS}

The following tests were used: Student's $t$ test for comparison of group means, Fisher's F test for comparison of group variances, and linear regression calculations for association between variables.

\section{Results}

The results of the mineral metabolic screen are summarised in Table 2. Both the corrected serum calcium and the serum ironised calcium concentrations were significantly raised $(P<0 \cdot 001)$. There was a significant correlation between the serum ionised calcium and the uncorrected serum calcium concentration $(r=0.55, P<0.05)$, and this became even more significant $(r=0.71, P<0.005)$ when the former was correlated with the corrected serum calcium level (Figs. 1a and b). The serum phosphate concentration was significantly reduced $(P<0 \cdot 01)$, and 10 patients had raised levels of serum alkaline phosphatase. Plasma chloride concentrations were significantly raised and 5 patients had increased calcium creatinine ratios. Five patients had reduced renal tubular reabsorption of phosphate $\left(\mathrm{TmPO}_{4} /\right.$ GFR) and 7 had increased phosphate excretion (IPE). When $\mathrm{Ca}_{\mathrm{E}}$ is plotted against total serum calcium concentration (Fig. 2) the results are to the right of the mean and 7 are outside the limits of normality, indicating increased renal tubular reabsorption of calcium (Marshall, 1976).

When the serum ionised calcium, serum phosphate and alkaline phosphatase are grouped according to
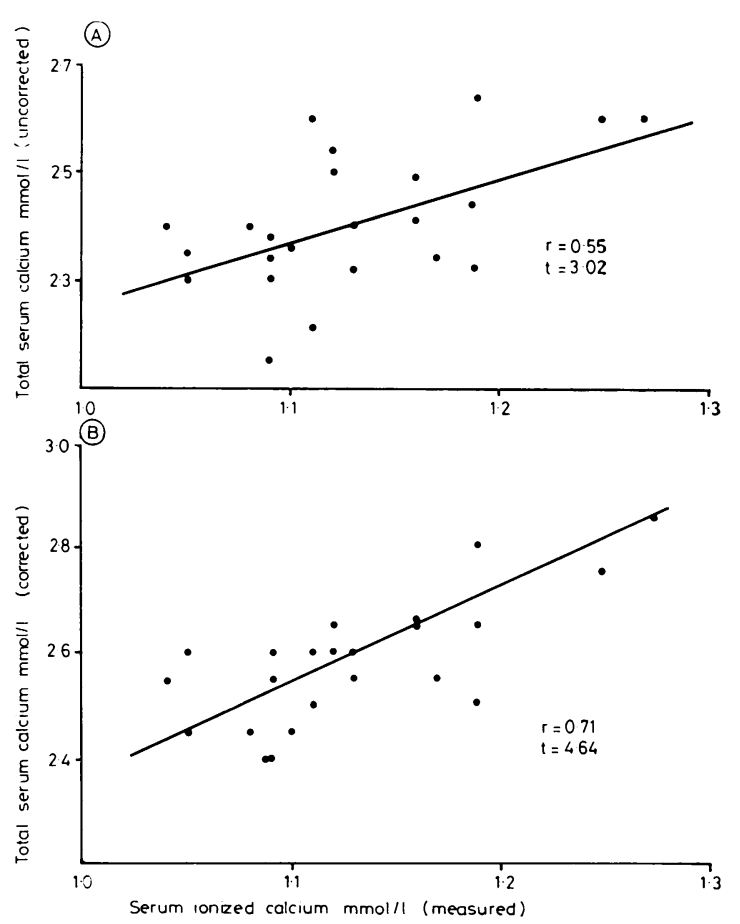

Fig. 1 Correlation between serum ionised calcium and (1a) total serum calcium not corrected for albumin concentration $(\mathrm{r}=0.55 ; \mathrm{P}<0.05) ;(1 \mathrm{~b})$ total sertum calcium corrected for albumin concentration $(\mathrm{r}=0.71$; $\mathrm{P}<0.005)$. 
404 Kennedy, Allam, Rooney, Watson, Fairney, Buchanan, Hillyard

Table 2 Results (mean $\pm S D$ ) of mineral metabolism screen in the patients with rheumatoid arthritis compared

\begin{tabular}{|c|c|c|c|c|c|c|c|c|}
\hline & $\begin{array}{l}\text { Serum } \\
\text { ionised } \\
\text { calcium } \\
\text { mmol/l }\end{array}$ & $\begin{array}{l}\text { Serum } \\
\text { calcium } \\
\text { (uncorrected) } \\
\text { mmol/l }\end{array}$ & $\begin{array}{l}\text { Serum } \\
\text { calcium } \\
\text { (corrected) } \\
\text { mmol /l }\end{array}$ & $\begin{array}{l}\text { Serum } \\
\text { phosphate } \\
\text { mmol/l }\end{array}$ & $\begin{array}{l}\text { Serum } \\
\text { alkaline } \\
\text { phosphatase } \\
\text { U/l }\end{array}$ & $\begin{array}{l}\text { Serum } \\
\text { albumin } \\
g / l\end{array}$ & $\begin{array}{l}\text { Plasma } \\
\text { bicarb. } \\
\text { mmol/l }\end{array}$ & $\begin{array}{l}\text { Plasma } \\
\text { sodium } \\
\text { mmol } / l\end{array}$ \\
\hline $\begin{array}{l}\text { Patient } \\
\text { group } \\
\text { Normal } \\
\text { reference } \\
\text { group }\end{array}$ & $1 \cdot 13 \pm 0.06$ & $2 \cdot 41 \pm 0 \cdot 13$ & $2 \cdot 58 \pm 0 \cdot 12$ & $0.98 \pm 0.2$ & $318 \pm(130-1490)$ & $38 \cdot 2 \pm 3 \cdot 9$ & $24 \cdot 3 \pm 2 \cdot 2$ & $139 \cdot 3 \pm 2$ \\
\hline ranges & $\begin{array}{l}1.07 \pm 0.05 \\
4 \cdot 23\end{array}$ & $2 \cdot 39 \pm 0 \cdot 1$ & $2 \cdot 39 \pm 0 \cdot 1$ & $\begin{array}{l}1 \cdot 1 \pm 0 \cdot 15 \\
2 \cdot 81\end{array}$ & $80-280$ & $\begin{array}{l}46 \cdot 9 \pm 3 \cdot 3 \\
9 \cdot 7\end{array}$ & $24 \cdot 5 \pm 1 \cdot 8$ & $140 \pm 2 \cdot 0$ \\
\hline $\begin{array}{l}\text { P } \\
\text { Number } \\
\text { above } \\
\text { reference }\end{array}$ & $<0.001$ & NS & $<0.001$ & $<0.01$ & $*$ & $<0.001$ & NS & NS \\
\hline $\begin{array}{l}\text { range } \\
\text { Number } \\
\text { below } \\
\text { reference } \\
\text { range }\end{array}$ & 0 & 1 & 7 & 0 & 10 & 4 & 1 & 0 \\
\hline
\end{tabular}

Statistical analysis invalid because of the non-normally distributed data.

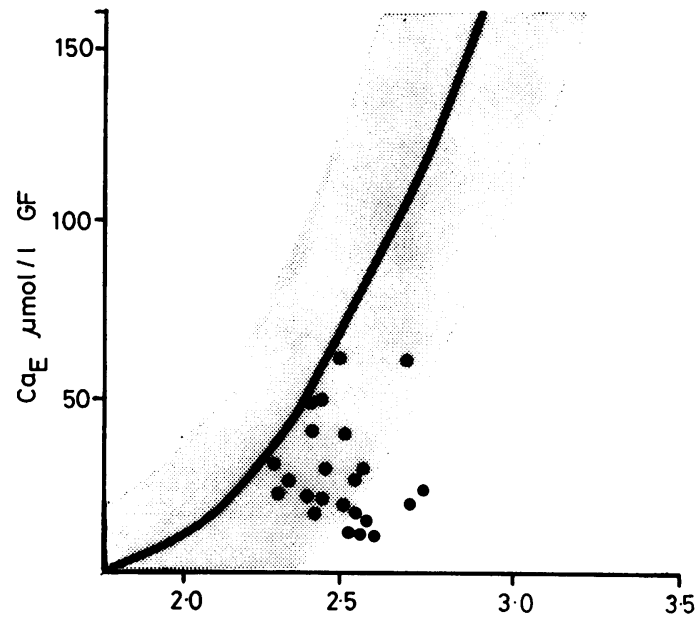

Total serum calcium $(\mathrm{mmol} / \mathrm{l})$

Fig. 2 Plot of calcium excretion $\left(\mathrm{Ca}_{E}\right)$ per litre of glomerular filtrate, against total serum calcium concentration. The shaded area represents the limits of normality.

their 'normality' (Table 3) the following facts emerge. Of the 23 patients only 7 had all 3 results in the 'normal' range. Of the 8 patients with raised serum ionised calcium 6 had biochemical patterns which might be encountered in a hypercalcaemic hyperparathyroid state. It can be seen in Table 4 that the mean serum alkaline phosphatase lies above the upper limit of the reference range. Indeed, 10 of the 23 patients had raised serum alkaline phosphatase levels, whereas there was no patient who showed increases of serum bilirubin, aspartate
Table 3 Grouping of combinations of 'normal' and 'abnormal' serum ionised calcium, phosphate and alkaline phosphatase results

\begin{tabular}{|c|c|c|c|}
\hline $\begin{array}{l}\text { Serum } \\
\text { ionised } \\
\text { calcium }\end{array}$ & $\begin{array}{l}\text { Serum } \\
\text { phosphate }\end{array}$ & $\begin{array}{l}\text { Serum } \\
\text { alkaline } \\
\text { phosphatase }\end{array}$ & $\begin{array}{l}\text { Number of } \\
\text { patients in } \\
\text { each group }\end{array}$ \\
\hline $\begin{array}{l}\mathbf{N} \\
\downarrow \\
\mathbf{N} \\
\mathbf{N} \\
\uparrow \\
\uparrow \\
\uparrow \\
\uparrow\end{array}$ & $\begin{array}{l}\mathbf{N} \\
\uparrow \text { or } \mathbf{N} \text { or } \downarrow \\
\mathbf{N} \\
\downarrow \\
\mathbf{N} \\
\mathbf{N} \\
\downarrow \\
\downarrow\end{array}$ & $\begin{array}{l}\mathbf{N} \\
\uparrow \text { or } \mathbf{N} \text { or } \downarrow \\
\uparrow \\
\mathbf{N} \\
\mathbf{N} \\
\uparrow \\
\mathbf{N} \\
\uparrow\end{array}$ & $\begin{array}{l}7(30.9 \%) \\
\overline{6}(26.0 \%) \\
2(8.6 \%) \\
2(8.6 \%) \\
3(13.0 \%) \\
2(8.6 \%) \\
1(4.3 \%)\end{array}$ \\
\hline
\end{tabular}

Table 4 The results (mean $\pm S D$ ) of serum alkaline phosphatase, bilirubin, SGOT and SGPT in the patients with rheumatoid arthritis, compared to the reference group.

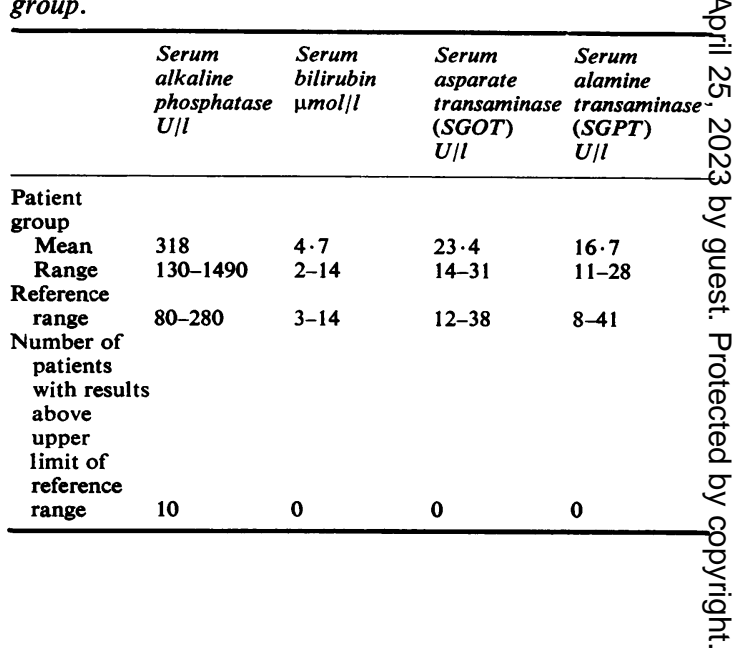


the normal reference group. Ranges or mean $\pm I S D$ when appropriate

\begin{tabular}{|c|c|c|c|c|c|c|c|c|}
\hline $\begin{array}{l}\text { Plasma } \\
\text { potassium } \\
\text { mmol/l }\end{array}$ & $\begin{array}{l}\text { Plasma } \\
\text { chloride } \\
\text { mmol/l }\end{array}$ & $\begin{array}{l}\text { Plasma } \\
\text { urea } \\
\text { mmol/l }\end{array}$ & $\begin{array}{l}\text { Serum } \\
\text { creatinine } \\
\text { mmol/l }\end{array}$ & $\begin{array}{l}\text { Maximum } \\
\text { tubular } \\
\text { reabsorption } \\
\text { of phosphate } \\
(\text { TmPOO } \\
\text { GFR })_{4 m o l / l}\end{array}$ & $\begin{array}{l}\text { Index of } \\
\text { phosphate } \\
\text { excretion } \\
(I P E)\end{array}$ & $\begin{array}{l}\text { Calcium/ } \\
\text { creatinine } \\
\text { ratio } \\
(\mathrm{mmol} / \mathrm{mmol})\end{array}$ & $\begin{array}{l}\text { TmCa/GFR } \\
\text { mmol/l }\end{array}$ & $\begin{array}{l}\text { Hydroxy- } \\
\text { proline/ } \\
\text { creatinine } \\
\text { ratio } \\
\text { mmol/mmol }\end{array}$ \\
\hline $4 \cdot 1 \pm 0 \cdot 5$ & $106 \pm 3 \cdot 3$ & $5 \cdot 4 \pm 1 \cdot 9$ & $83 \pm 30$ & $0.96 \pm 0 \cdot 36$ & $+0.25 \pm 0.17$ & $0 \cdot 38 \pm 0 \cdot 28$ & $2 \cdot 04 \pm 0 \cdot 35$ & $0.018 \pm 0.016$ \\
\hline $4 \cdot 2 \pm 0 \cdot 4$ & $\begin{array}{l}100 \pm 2 \cdot 5 \\
8 \cdot 53\end{array}$ & $2 \cdot 7-7 \cdot 0$ & $35-115$ & $0 \cdot 70-135$ & $0 \cdot 70-1 \cdot 35$ & $0.06-0.46$ & $1.68-2.08$ & 0.02 \\
\hline NS & $<0.001$ & NS & NS & * & $*$ & $*$ & * & $*$ \\
\hline 1 & 9 & 3 & 1 & 2 & 7 & 5 & 12 & 6 \\
\hline 3 & 0 & 0 & 0 & 5 & 0 & 1 & 0 & 0 \\
\hline
\end{tabular}

transaminase (AST), or alanine transaminase (ALT). One patient had extremely high serum alkaline phosphatase, and this was associated with the highest serum ionised calcium in our patients. The results of the urinary hydroxyproline showed that 9 of the patients studied had levels in excess of normal limits $(0.05-0 \cdot 17 \mathrm{mmol} / 24 \mathrm{~h})$. However, when these results were subsequently calculated for accuracy of interpretation in terms of the hydroxyproline/creatinine ratio only 6 patients had abnormally high results. Since the urinary hydroxyproline and the fasting calcium/creatinine ratio suggest evidence of bone destructions (Nordin et al., 1976) the results for urinary calcium and urinary hydroxyproline levels were correlated in the patients studied (Fig. 3). It can be seen that there is a statistically significant positive correlation $(\mathrm{r}=0.54, \mathrm{P}<0.005)$ between these indices.

The results of the immunoreactive parathormone assay (Fairney et al., 1973) and other hormone assays are shown in Table 5. It can be seen that no patient had an elevated parathormone level, and indeed in 16 the level was below the lower limit of the normal range. In the other assay (Berson et al., 1963) all levels lay within the normal range. Only one patient (patient 11) had an raised serum immunoreactive gastrin level: this patient also had raised serum calcitonin and ionised calcium levels, a low parathyroid hormone (PTH) level, and the highest serum alkaline phosphatase. The patient with the low 25-OH vitamin D level (patient 23) had a markedly raised urinary D-glucaric acid concentration. This patient had been receiving phenobarbitone for epilepsy. Serum magnesium concentrations $(0 \cdot 80 \pm$ $0.06 \mathrm{mmol} / \mathrm{l})$ were within normal limits.

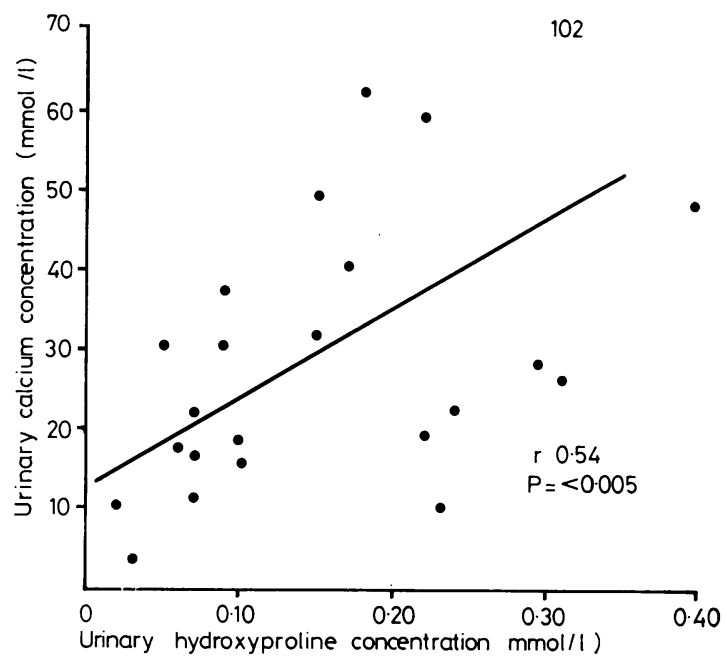

Fig. 3 Correlation between the calcium ratio and the hydroxyproline ratio derived from fasting urine samples $(\mathrm{r}=0.54 ; \mathrm{P}<0.005)$.

Patients with an elevated serum ionised calcium level tended to have lower serum phosphate levels and TmP/GFR and higher TmCa/GFR (Table 6). No significant differences were noted in the clinical and other laboratory features between the patients with elevated and normal serum ionised calcium levels.

Analysis of the bone damage indices revealed a significant correlation between the erosion score and the metacarpal index $(\mathrm{r}=0.6, \mathrm{P}<0.01)$ and the erosion score and joint space narrowing score 


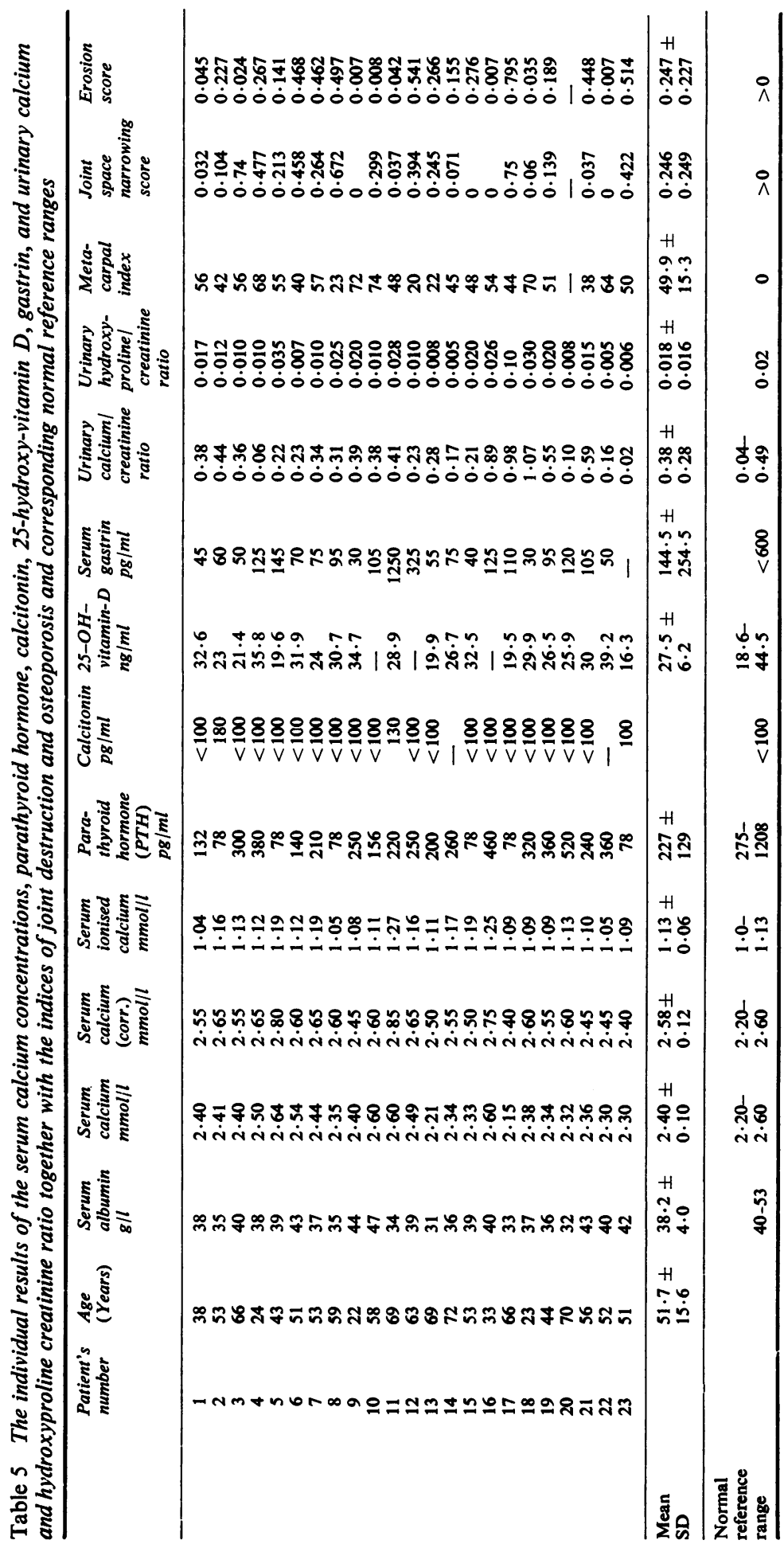


Table 6 Comparison of the biochemical data between the normocalcaemic and hypercalcaemic patients as determined by their ionised calcium concentration

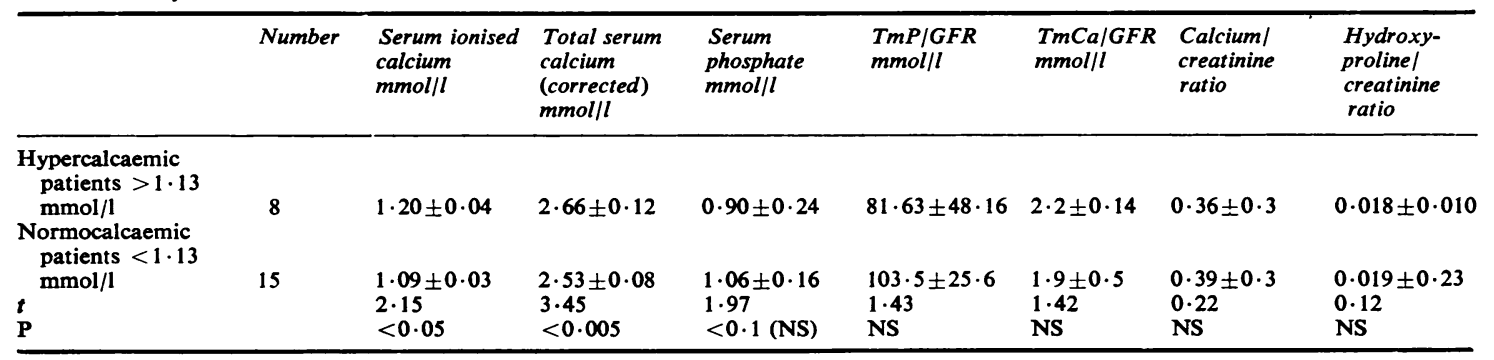

$(\mathrm{r}=0.77, \mathrm{P}<0.001)$. No correlation existed between serum ionised calcium concentration and any of these bone damage indices.

\section{Discussion}

Bone loss is an important clinical facet of rheumatoid arthritis. When severe osteoporosis is present, compression fractures of the vertebrae may occur, and in peripheral bones thinning of cortical bone may complicate joint surgery. So far there has been little evidence that osteoporosis in rheumatoid arthritis has a 'metabolic' basis, and it was therefore of interest when we observed that a high proportion of patients had raised serum calcium concentrations when the serum calcium was corrected for the low albumin concentration (Kennedy et al., 1975). It seemed relevant, therefore, to study in greater depth the pathogenesis of hypercalcaemia in rheumatoid arthritis. To this end 50 female patients with rheumatoid arthritis were randomly selected and screened for possible hypercalcaemia after correction of serum calcium for hypoalbuminaemia. Twentythree of these patients with 'definite' or 'classical' rheumatoid arthritis were shown to have an elevated corrected serum calcium concentration and were chosen for detailed investigation of biochemical and hormonal aspects of calcium metabolism.

The first and most crucial question is whether or not the serum ionised calcium estimations validly support the contention that hypercalcaemia in rheumatoid arthritis is a real entity. The study was carefully controlled both in terms of matching patients for age and sex with healthy persons and in the methods employed to determine serum ionised calcium concentrations. The patients and controls were studied in the fasting state, and particular care was taken in withdrawal of venous blood to ensure that no air entered the syringe and that the arm was not constricted. The patients and controls were studied contemporaneously and the laboratory estimations were performed under identical con- ditions. The temperature at which the estimations were performed was constant $\left(37^{\circ} \mathrm{C}\right)$ for all samples, and the results were corrected for $\mathrm{pH}$ and sodium interference. Hence there are strong grounds for accepting that 8 of the 23 patients with rheumatoid arthritis did have raised serum ionised calcium concentrations.

It might be argued that the mean control value of serum ionised calcium concentration was somewhat lower $(1.07 \mathrm{mmol} / \mathrm{l})$ than that reported by other workers. However, it is extremely difficult to make comparisons of normal values obtained in different laboratories, in particular when there are so many variables which can affect such results. Moreover, a literature survey revealed that only 3 other groups have reported serum ionised calcium determinations using the ion electrode method employed in the present study while also studying patients in the fasting state. Robertson and Peacock (1968) and Ladenson and Bowers (1973) both obtained higher mean values, 1.23 and $1.28 \mathrm{mmol} / 1$ respectively, but Ryden et al., (1976) obtained a mean value of $1.03 \mathrm{mmol} / \mathrm{l}$, which was lower than that obtained in the control subjects in the present study. It should be noted that Ladenson and Bowers (1973) carried out their estimations at a temperature of $25^{\circ} \mathrm{C}$, which would tend to increase the serum ionised calcium result. Ryden and her colleagues (1976) do not, unfortunately, state the temperature at which they carried out their estimations. Varghese (1973), using spectrophotometry, obtained a mean value slightly lower $(1.04 \mathrm{mmol} / \mathrm{l})$ than that obtained in the present study. His subjects were also fasting and the working temperature was $37^{\circ} \mathrm{C}$. The reproducibility of the method employed in the present study was high, with a coefficient of variation of $0.76 \%$ in 20 samples from the same bulk source (Watson, 1975). Thus it seems reasonable to conclude that the 8 patients with rheumatoid arthritis had definite, though in some patients slight, elevations in serum ionised calcium levels.

Further confirmation of the finding of raised serum 
ionised calcium levels in rheumatoid arthritis has been obtained in a study of 52 patients with the disease studied in South Africa. Approximately one-third (17) of the patients had raised serum ionised calcium levels when compared to a healthy control group matched for age and sex (Meyers et al., 1976). This method employed an Orion calcium ion exchange electrode model SS-20 and the temperature at which estimations were performed was $37^{\circ} \mathrm{C}$. The correction factor employed in the present study is also central to the investigation, and its validation is therefore crucial. As previously indicated, the regression line of serum calcium concentration on serum albumin level when extended to the $Y$ axis when the albumin concentration is zero intersects at $1.43 \mathrm{mmol} / \mathrm{l}$, which corresponds to the serum ultrafilterable calcium concentration found by others (Robertson, 1969; Pedersen, 1970; Rose, 1972; Payne et al., 1973). Of great importance is whether there is concordance between hypercalcaemia estimated from the correction formula and hypercalcaemia confirmed by a high value of serum ionised calcium. Of the 23 patients with rheumatoid arthritis in the present study, 7 had hypercalcaemia as estimated by the correction formula for a low serum albumin concentration. Six of these 7 patients had elevated serum ionised calcium levels. Patient 4 (Table 5), who had a normal value for serum ionised calcium $(1.12 \mathrm{mmol} / \mathrm{l})$ had a corrected total serum calcium concentration just over the upper limit of normal $(2.65 \mathrm{mmol} / \mathrm{l})$. Of the 16 patients who had normal values for corrected serum calcium concentrations 2 had increases of serum ionised calcium (patients 14 and 15; Table 5). There is thus reasonable concordance between the corrected total serum ionised calcium concentration and the serum ionised calcium level, and this tends to support the validity of the correction formula. Further support is provided by the fact that the correlation between serum ionised calcium concentration and the corrected total serum calcium level $(r=0 \cdot 71$, $P<0.005)$ is higher than with the uncorrected total serum calcium $(\mathrm{r}=0.55, \mathrm{P}<0.05)$.

The serum ionised calcium is the physiologically active fraction of total serum calcium, and consequently, when raised, it is of clinical significance. The associated biochemical results of the mineral metabolism screen are therefore of interest. The finding of hypophosphataemia, increased serum alkaline phosphatase, hyperchloraemia, reduced tubular reabsorption of phosphate, and increased tubular reabsorption of calcium suggest possible parathyroid overactivity. The elevation of serum alkaline phosphatase in patients with rheumatoid arthritis may be of either bone (Maddison and Bacon, 1974) or liver origin (Webb et al., 1975). Unfortu- nately, isoenzyme studies were not available to determine the source of the increased serum alkaline $\overrightarrow{\vec{s}}$ phosphatase levels in the present study. However $\frac{\vec{O}}{\square}$ none of the patients had clinical evidence of livet disease, and all had normal serum levels of bilirubin and the enzymes AST and ALT. It is of interest that of 6 patients with elevated hydroxyproline/creatinine ratios 4 had elevated serum alkaline phosphatases levels. However, 6 patients with elevated serump alkaline phosphatase levels had normal hydroxy $\vec{\overrightarrow{ }}$ proline/creatinine ratios. Increased hydroxyprolinew excretion in the urine reflects an increased turnovere of collagen, and has been reported by some (Hart? mann et al., 1969) but not all workers (Ziff et al. $\infty$ 1956) in patients with rheumatoid arthritis. The significant correlation between the increased urinary calcium and hydroxyproline results (Fig. 3) suggestso that the underlying cause for this is likely to be increased bone turnover.

The question arises whether this evidence sug gesting increased bone turnover and the othero biochemical abnormalities noted might be interpreted as indicating hyperparathyroid activity. It is there- $\vec{\theta}$ fore of interest that patients who had raised serume ionised calcium level tended to have lower serumb phosphate levels and TmP/GFR and higher TmCa/s GFR. Thus, one can only tentatively conclude that there is some evidence of increased bone turnovero and possible parathyroid overactivity. In this con-क्ष text the results of the hormone assays were of particular interest.

The most accurate test for parathyroid overactivity is regarded as the direct measurement of serum PTH. By both methods of immunoassay employed in this study the serum levels of $\mathrm{PTH}_{2}$ were normal or reduced. Serum calcitonin levelso were elevated in two patients only, and it is of interest that 1 of those had the highest serum ionisedô calcium concentration (patient 11, Table 5). The cause of the elevated calcitonin level may be a res-윽 ponse to the elevation of serum ionised calcium as $>$ has been shown in some mammalian species (Gray을 and Munson, 1969), but not yet in man (Schneider ज and Sherwood, 1974).

Hypercalcaemia and hyperparathyroidism may be $\tilde{O}^{0}$ associated with hypergastrinaemia (Turbey and N Passaro, 1972; Barreras, 1973), and rheumatoido arthritis may also be associated with high serumo immunoreactive gastrin levels (Rooney et al., 1976). This suggests a possible link between enteric hor- $-?$ mones and anomalies in calcium metabolism 0 occurring in rheumatoid arthritis. However, only $1 \stackrel{\vec{P}}{\circ}$ of the patients in the present study (patient 11, Table $\mathrm{Q}$ 5) had a raised serum immunoreactive gastrin level, $\stackrel{\mathbb{Q}}{\stackrel{2}{ }}$ though it is of interest that this patient had the highest serum ionised calcium concentration. In 
addition this patient had a raised serum calcitonin level, and it might be due to the fact that hypergastrinaemia can stimulate calcitonin secretion in man (Hennessy et al., 1973). Serum glucagon levels were normal in all patients studied.

The role of vitamin $\mathbf{D}$ in calcium metabolism in patients with rheumatoid arthritis has not been thoroughly investigated. In a recent study of 5 patients with rheumatoid arthritis bone biopsy. showed osteomalacia and secondary hyperparathyroidism, and these findings were considered to be secondary to a dietary deficiency of vitamin $D$, assessed retrospectively by dietary histories (Maddison and Bacon, 1974). However, the analysis of serum 25-hydroxy-vitamin $D$ levels in this study revealed only 1 abnormally low result, in a patient with associated high level of urinary D-glucaric acid who was receiving phenobarbitone for treatment of epilepsy. It seems reasonable to postulate that the low level of vitamin D was due to liver microsomal enzyme induction secondary to anticonvulsant therapy (Hahn et al., 1972; Rowe and Stamp, 1974). A number of antirheumatic drugs are also known to be associated with liver microsomal enzyme induction in experimental animals (Conney, 1967), but there was no evidence of this occurring in patients in the present study as judged by urinary $\mathrm{D}$-glucaric acid levels.

The patients in Maddison and Bacon's study were selected because they had bone fractures and they tended to be older and more severely affected by the arthritis than the patients in this study. In addition it seems germane to note that in the radiological studies of skeletal status in very large numbers of patients with rheumatoid arthritis previously reported no circumstantial evidence of osteomalacia was found (Kennedy and Lindsay, 1977). In addition, the absence of supportive biochemical evidence in a prior study (Kennedy et al., 1975) would seem to suggest that the incidence of hypovitaminosis $\mathbf{D}$ is probably confined to a very small select group of the rheumatoid population and indeed perhaps not to any greater extent than that in the general population.

Examination of the indices of articular bone damage showed significant correlation between the erosion score and the metacarpal index, tending to suggest that whatever is occurring at the joint surface is also being reflected at the midpoint of the shaft of the metacarpal. Thus, the metacarpal index would seem to provide a reasonably simple guide to the extent of bone damage occurring in the hand of a rheumatoid patient. There was also a good correlation between the erosion score (Dc) and the joint space narrowing score (JSNc), suggesting that the development of bony defects parallels the development of cartilage destruction.
None of the patients in this study had any evidence of any alternative disease which could have explained the hypercalcaemia such as the milk-alkali syndrome, hypervitaminosis $\mathrm{D}$, sarcoidosis, or malignancy. It is possible that the increased serum calcium concentrations might be due simply to erosion of bone, in which case it might be anticipated that they would correlate with activity of joint disease as judged by clinical, laboratory, and radiological parameters. There was no such correlation between hypercalcaemia and disease activity based on the patient's pain index, articular index of joint tenderness, functional grade, haemoglobin concentration, erythrocyte sedimentation rate, and serum protein concentration, nor with the radiological indices of bone damage. However, this does not totally exclude the possibility of any influence of disease activity on the production of hypercalcaemia, since the number of patients studied was small and the disease relatively long standing. Nevertheless, the fact that the hypercalcaemia is apparently not a constant feature for any one patient could be consistent with variation in the rate of bone destruction, which is not an unlikely possibility in a disease with such clinical variation.

Another variable which might explain the elevated serum ionised calcium levels is administration of antirheumatic drugs. None of the patients had taken any medication within 12 hours of the study, but persistence of drug effect cannot be discounted. Also it is possible that non-steroidal anti-inflammatory drugs or corticosteroids may interfere with plasma binding of calcium, thus producing abnormalities in serum ionised calcium measurements. Against, this however, is the fact that all the patients in this study had had no drug therapy for a minimum of 12 hours before its start, and additionally there is no reported evidence that these drugs do produce interference in this way.

It might be argued that cessation of therapy in itself could cause a release of calcium from its binding sites on albumin. However, it is of interest that the patients with rheumatoid arthritis studied in South Africa (Meyers et al., 1976) had approximately the same incidence $(30 \%)$ of increased serum ionised calcium levels and all were currently receiving nonsteroidal anti-inflammatory drugs. Northover (1973), using amounts of indomethacin in excess of normal therapeutic doses, has shown in vitro that the drug will reduce calcium binding to the membranes of endothelial cells, but the relevance of this single observation to the present clinical studies is not apparent. Careful search of the literature has failed to find any other publication on the effects of nonsteroidal anti-inflammatory drugs on serum ionised calcium determinations. 
If hyperparathyroidism is not the cause of the increased serum ionised calcium concentrations and the other biochemical abnormalities observed, the question arises of what they may be due to. The situation in rheumatoid arthritis has some resemblance to that pertaining to increased serum ionised calcium concentrations in neoplasm, where in the presence of biochemical evidence strongly suggestive of hyperparathyroidism immunoassay of PTH may be normal (Heath, 1976; Woodhead and Walker, 1976). Conceivably in rheumatoid arthritis and in certain neoplasms polypeptides may be produced which have PTH-like activity but cannot yet be measured by the current immunoassay procedures. An alternative explanation is that the hypercalcaemia may be the result of effects of prostaglandin $E_{2}$. Prostaglandin levels are increased in the synovial fluid in rheumatoid arthritis (Higgs et al., 1974), and Robinson et al. (1975) have shown in bone culture studies in vitro that all the bone-resorption-stimulating activity in rheumatoid synovial fluid can be accounted for by prostaglandin $E_{2}$.

Krane (1974) also demonstrated bone resorbing factor from synovial cell culture media but did not consider this to be due to prostaglandin $\mathrm{E}_{2}$. To date no measurement has been made of prostaglandin $E_{2}$ in the sera of patients with rheumatoid arthritis, but conceivably this, if it were raised, could cause bone resorption and hypercalcaemia. It is not known whether prostaglandin $E_{2}$ could account for the other biochemical abnormalities of mineral metabolism observed in the present study, and clearly this is worthy of further study. It is interesting to note that sera from patients with rheumatoid arthritis have been shown to cause resorption of bone in tissue culture and that this effect was most marked in serum with high calcium concentrations (Kennedy et al., 1976).

Another substance with PTH-like action is osteoclast-activating factor, OAF (Horton et al., 1972), a substance which has been isolated from lymphocytes. The effects of OAF on bone in vitro resemble those of PTH (Raisz et al., 1975), but effects of injection of equipotent in vitro doses of the 2 substances in vivo in rats differ in that PTH affects serum calcium and phosphate while OAF does not, suggesting that OAF is a local rather than a systemic bone resorbing factor. This would also seem an obvious area for further investigation. Biochemical effects particularly regarding renal handling of calcium and phosphate have, like $\mathrm{PGE}_{2}$, not been studied with OAF, and clearly require further investigation.

In conclusion, the results of the present study indicate that hypercalcaemia is a not uncommon feature of rheumatoid arthritis. The hypercalcaemia is associated with biochemical abnormalities sug gestive of hyperparathyroidism, but serum con centrations of immunoreactive parathyroid hormoneo are normal. Since sera of patients with rheumatoiff arthritis, especially those with hypercalcaemia, $\overline{\bar{s}}$. cause bone resorption in vitro (Kennedy et al., 1976) there seems little doubt that bone loss in rheumatoido arthritis is an active process. Finally, the fact that calcitonin and hydrocortisone block the resorptive effect of rheumatoid sera on bone in vitro (Kennedy $\overrightarrow{\vec{\omega}}$ and Lindsay, 1977) may have therapeutic possibilities

We thank the technical staff of the University Department of Pathological Biochemistry, Glasgow Royal Infirmary, fofo their help. We wish to acknowledge the generous financiaf support of the National Fund for Research into Crippling Diseases, and the Arthritis and Rheumatism Council for Research in Great Britain. One of us (A.C.K.) was in receip? of a Medical Research Council Clinical Research Fellow= ship.

\section{References}

Barnett, E., and Nordin, B. E. C. (1960). The radiologicato diagnosis of osteoporosis-a new approach. Clinical Radiology, 11, 166-174.

Barreras, R. F. (1973). Calcium and gastric secretion Gastroenterology, 64, 1168-1184.

Berson, S. A., Yalow, R. S., Aurbach, G. D., and Potts్ J. T. Jr. (1963). Immunoassay of bovine and humapo parathyroid hormone. Proceedings of the National Academ $\Omega$ of Sciences of the United States of America, 49, 613-617

Bijvoet, O. L. (1969). Relation to plasma phosphate concentation to renal tubular reabsorption of phosphate Clinical Science, 37, 23-36.

Bijvoet, O. L., Morgan, D. B., and Fourman, P. (1969) The assessment of phosphate reabsorption. Clinica Chimica Acta, 26, 15-24.

Boehringer, Mannheim GMBH Diagnostica. Alkaline phosphatase optimised standard method kit. Catalogue. No. 15990.

Buchanan, K. D. (1973). Ph.D. thesis. The Queen's Universit of Belfast.

Buchanan, K. D., and McCarroll, A. M. (1971). In Radio immunoassay Methods, p. 136. Edited by K. E. Kirkham and W. M. Hunter. Edinburgh: Livingstone.

Conney, A. H. (1967). Pharmacological implications of microsomal enzyme induction. Pharmacological Review o 19, 317-366.

Coombes, R. C., Hillyard, C., Greenberg, P. B., and MC Intyre, I. (1974). Plasma immunoreactive calcitonin in patients with non-thyroid tumour. Lancet, 1, 1080-1083.

Fairney, A., Jackson, D., and Clayton, B. E. (1973). Measure ment of serum parathyroid hormone with particulem reference to some infants with hypocalcaemia. Archive्त of Disease in Childhood, 48, 419-424.

Flanagan, R. W. J., Buchanan, K. D., and Murphy, R. F. (1974). Specificity of antibodies in the radioimmunoassa of glucagon. Diabetologia, 10, 365-369.

Goverde, B. C., and Veenkamp, F. J. (1972). Routine assa of total hydroxyproline based on resin catalysed hydrolysis Clinica Chimica Acta, 41, 29-40.

Gray, T. K., and Munson, P. L. (1969). Thyrocalcitonip evidence for physiological function. Science, 166, 512-513 
Haddad, J. G., and Chyu, K. G. (1971). Competitive protein binding radioassay for 25 hydroxycholecalciferol. Journal of Clinical Endocrinology and Metabolism, 33, 992-995.

Hahn, T. J., Birge, S. J., Scharp, C. R. and Avioli, L. V. (1972). Phenobarbital induced alterations in vitamin D metabolism. Journal of Clinical Investigation, 51, 741-748.

Hartmann, F., Rohde, J., Schmidt, A. (1969). Aktivitätsdiagnostik bei der primar-chronischen polyarthritis. Zeitschrift für Rheumatologie, 28, 263-266.

Heath, D. A. (1976). Hypercalcaemia and malignancy. Annals of Clinical Biochemistry, 13, 555-561.

Hennessy, J. F., Gray, T. K., Cooper, C. W., and Ontjes, D. A. (1973). Stimulation of thyrocalcitonin secretion by penetagastrin and calcium in 2 patients with medullary carcinoma of the thyroid. Journal of Clinical Endocrinology and Metabolism, 36, 200-203.

Higgs, G. A., Vane, J. R., Hart, F. O., and Wojulewski, J. A. (1974). The effects of anti-inflammatory drugs on prostaglandin concentrations in synovial fluid from patients with rheumatoid arthritis. In Prostaglandin Synthetase pp. 165171. Edited by H. J. Robinson and J. R. Vane. Raven Press: New York City.

Horton, J. E., Raisz, L. G., Simmons, H. A., Oppenheim, J. T., and Mergenhagen, S. E. (1972). Bone resorbing activity in supernatant fluid cultured from human peripheral blood leucocytes. Science, 177, 793-795.

Jones, J. H., Peters, D. K., Morgan, D. B., Coles, G. A., and Mallick, N. P. (1967). Observations on calcium metabolism in the nephrotic syndrome. Quarterly Journal of Medicine, 36, 301-320.

Kennedy, A. C., Allam, B. F., Boyle, I. T., Nuki, G., Rooney, P. J., and Buchanan, W. W. (1975). Abnormalities in mineral metabolism suggestive of parathyroid overactivity in rheumatoid arthritis. Current Medical Research and Opinion, 3, 345-358.

Kennedy, A. C., Lindsay, R., Buchanan, W. W., and Allam, B. F. (1976). Bone-resorbing activity in the sera of patients with rheumatoid arthritis. Clinical Science and Molecular Medicine, 51, 205-207.

Kennedy, A. C., and Lindsay, R. (1977). Bone involvement in rheumatoid arthritis. Clinics in the Rheumatic Diseases, $3,403-420$.

Krane, S. M. (1974). Degradation of collagen in connective tissue diseases. Rheumatoid arthritis. In Dynamics of Connective Tissue Macromolecules, 7th edn. McGraw Hill: New York.

Ladenson, J. H., and Bowers, G. N. (1973). Free calcium in serum II. Rigor of homeostatic control correlations with total serum calcium and review of data on patients with disturbed calcium metabolism. Clinical Chemistry, 19, 575-582.

McLaughlin, M., Fairney, A., Lester, E., Raggatt, P. R., Brown, D. J., and Wills, M. R. (1974). Seasonal variations in serum 25-hydroxycholecalciferol in healthy people. Lancet, 1, 536.

Maddison, P. J., and Bacon, P. A. (1974). Vitamin D deficiency, spontaneous fractures and osteopenia in rheumatoid arthritis. British Medical Journal, 4, 433-435.

Marshall, R. W. (1976). In Calcium, Phosphate and Magnesium Metabolism, pp. 290-294. Edited by B. E. C. Nordin. Churchill-Livingstone: Edinburgh, London, and New York.

Meyers, A. M., Laidley, L., Levine, E., Milne, F. J., Salant, D., and Kennedy, A. C. (1976). Ionized calciums in renal and other metabolic osteodystrophies. Communication to the Association of Physicians of South Africa. The University of the Orange Free State, Bloemfontein, South Africa.
Nordin, B. E. C., Hodgkinson, A., and Peacock, M. (1967). The measurement and meaning of urinary calcium. Clinical Orthopaedics and Related Research, 52, 293-322.

Nordin, B. E. C., and Bulusu, L. (1968). A modified index of phosphate excretion. Postgraduate Medical Journal, 44, 93-97.

Nordin, B. E. C., Horsman, A., and Aaron, J. (1976). In Calcium, Phosphate and Magnesium Metabolism, pp. 471473. Edited by B. E. C. Nordin. Churchill-Livingstone: Edinburgh, London, and New York.

Northover, B. J. (1973). Effect of anti-inflammatory drugs on the binding of calcium to cellular membranes in various human and guinea-pig tissues. British Journal of Pharmacology, 48, 496-504.

Orrell, D. H. (1971). Albumin as an aid to the interpretation of serum calcium. Clinica Chimica Acta, 35, 483-489.

Paterson, C. R. (1973). Tests of phosphate reabsorption. Lancet, 1, 1251.

Payne, R. B., Little, A. J., Williams, R. B., and Milner, J. R. (1973). Interpretation of serum calcium in patients with abnormal serum proteins. British Medical Journal, 4, 643-646.

Pedersen, K. O. (1970). Determination of calcium fractions of serum. II. Ionized calcium in ultrafiltrates of normal serum and examination of pertinant variables. Scandinavian Journal of Clinical and Laboratory Investigations, 25, 223-230.

Pedersen, K. O. (1972). Binding of calcium to serum albumin. II. Effects of $\mathrm{pH}$ via competitive hydrogen and calcium ion binding to imidazole groups of albumin. Scandinavian Journal of Clinical and Laboratory Investigations, 29, 75-83.

Raisz, L. G., Trummel, C. L., Mundy, G. R., and Luben, R. A. (1975). Immunological factors influencing bone resorption, role of osteoclast activating factor from human lymphocytes and complement mediated prostaglandin synthesis. In Calcium Regulating Hormones, Proceedings of the Fifth Parathyroid Conference. Edited by R. V. Talmage, M. Owen, and J. A. Parsons. Excerpta Medica: Amsterdam.

Robertson, W. G., and Peacock, M. (1968). New techniques for the separation and measurement of the calcium fractions of normal human serum. Clinica Chimica Acta, 20, 315-326.

Robertson, W. G. (1969). Measurement of ionized calcium in biological fluids. Clinica Chimica Acta, 24, 149-157.

Robinson, D. R., Tashjian, A. H. Jr., and Levine, L. (1975). A possible mechanism for bone destruction in rheumatoid arthritis. Journal of clinical Investigation, 56, 1181-1188.

Rooney, P. J., Kennedy, A. C., Gray, G. H., Sturrock, R. D., Buchanan, K. D., and Dick, W. C. (1976). Serum immunoreactive gastrin (IRG) in rheumatoid arthritis: further observations on its identity, clinical specificity and relationship to gastric function. Annals of the Rheumatic Diseases, 35, 246-251.

Ropes, M. W., Bennet, G. A., Cobb, S., Jacox, R., and Jessar, A. R. (1959). Proposed diagnostic criteria for rheumatoid arthritis. Annals of Rheumatic Diseases, 18, 49.

Rose, G. A. (1972). A simple and rapid method for the measurement of plasma ultrafiltrable and ionised calcium. Clinica Chimica Acta, 37, 343-349.

Rowe, D. J., and Stamp, T. C. (1974). Anticonvulsant osteomalacia and vitamin D. British Medical Journal, 1, 392.

Ryden, S. E., Kirkish, L. S., and McCann, D. S. (1976). Evaluation of serum ionic calcium measurement in a general hospital population. American Journal of Clinical Patho$\log y, 66,634-638$. 


\section{Kennedy, Aliam, Rooney, Watson, Fairney, Buchanan, Hillyard}

Schneider, A. B., and Sherwood, L. M. (1974). Calcium homeostasis and the pathogenesis and management of hypercalcaemic disorders. Metabolism, 23, 975-1007.

Sharp, J. T., Lidsky, M. D., Collins, L. C., and Moreland, J. (1971). Methods of scoring the progression of radiologic changes in rheumatoid arthritis. Arthritis and Rheumatism, 14, 706-720.

Simmons, C. J., Davis, M., Dordoni, B., and Williams, R. (1974). Urinary D-glucaric acid assay by an improved enzymatic procedure. Clinica Chimica Acta, 51, 47-51.

Turbey, W. J., and Passaro, E. Jr. (1972). Hyperparathyroidism in the Zollinger-Ellison Syndrome. Archives of Surgery, 105, 62-66.

Varghese, Z. (1973). Determination of plasma calcium fractions. Annals of Clinical Biochemistry, 10, 120-129.
Watson, M. (1975). Ph.D. thesis. University of Glasgow.

Webb, J., Whaley, K., MacSween, R. N., Nuki, G., Dick, $\overrightarrow{\overline{\vec{\omega}}}$ W. C., and Buchanan, W. W. (1975). Liver disease in rheumatoid arthritis and Sjögren's syndrome. Prospective study using biochemical and serological markers of $\overline{\bar{D}}$ hepatic dysfunction. Annals of the Rheumatic Diseases, $34,70-81$.

Woodhead, J. S., and Walker, D. A. (1976). Assay of parathyroid hormone in human serum and its use. Annals of $\mathrm{c}$ Clinical Biochemistry, 13, 549-555.

Ziff, M., Kibrick, A., Dresner, E., and Giribetz, H. L. (1956). Excretion of hydroxyproline in patients with rheumatic $\vec{\omega}$ and non-rheumatic diseases. Journal of Clinical Investigation, 35, 579-583. 